\title{
Impacts of Environmental Factors on Waste, Energy, and Resource Management and Sustainable Performance
}

\author{
Mohd Helmi Ali ${ }^{1, *(\mathbb{D}) \text {, Suhaiza Zailani }}{ }^{2}$, Mohammad Iranmanesh ${ }^{3}(\mathbb{D})$ and Behzad Foroughi ${ }^{3}(\mathbb{D}$ \\ 1 Faculty of Economics and Management, Universiti Kebangsaan Malaysia, Selangor 43600, Malaysia \\ 2 Faculty of Business and Accountancy, University of Malaya, Kuala Lumpur 50603, Malaysia; \\ shmz@um.edu.my \\ 3 Graduate School of Business, Universiti Sains Malaysia, Penang 11800, Malaysia; \\ iranmanesh@usm.my (M.I.); foroughi@usm.my (B.F.) \\ * Correspondence: mohdhelmiali@ukm.edu.my
}

Received: 18 February 2019; Accepted: 29 March 2019; Published: 25 April 2019

\begin{abstract}
The management of waste, energy, and resources has received special attention from academics and practitioners due to the growing evidence for its effects on the environment. The aim of this study is to investigate the environmental drivers of waste, energy, and resource management and, in turn, its effect on the sustainable performance of manufacturing firms. The data were collected from a survey of 173 large manufacturing firms in Malaysia and analysed using partial least squares. The results indicate that although environmental regulatory pressure, customer pressure, environmental uncertainty, and expected business benefits have positive effects on the extent of waste, energy, and resource management, social responsibility has no effect. Furthermore, waste, energy, and resource management has a positive effect on the sustainable performance of large manufacturing firms. The findings of this study extend the knowledge of the drivers and outcomes of waste, energy, and resource management. The results can help policymakers to adjust policies and strategies in a way to inspire managers to implement waste, energy, and resource management.
\end{abstract}

Keywords: environmental factors; waste management; energy management; resource management; sustainable performance

\section{Introduction}

Industrialization has been rapid in most Asian countries, including China, Indonesia, and Malaysia. Although industrialization and manufacturing have considerable social and economic benefits [1], they consume both renewable and non-renewable materials, as well as significant amounts of energy [2], and they cause land, water, and air pollution [3]. Considering the existence of several global environmental problems, such as global warming and ozone depletion, there is increasing pressure from customers, governments, and non-governmental organizations (NGOs) on manufacturers to act responsibly towards the environment and future generations, and to consider the environmental impacts of their activities [4,5]. Additionally, pressures from stakeholders and also material costs and scarcity push manufacturers to move towards sustainable manufacturing practices, such as reducing material and energy consumption as well as waste generation [6]. As such, research on waste, energy, and resource (WER) management has received special attention $[7,8]$.

Previous studies on WER management in the context of manufacturing have taken different directions. One group has examined techniques and practices to minimize resource and energy usage and waste generation $[9,10]$. A second group has investigated the challenges of WER management and sustainable manufacturing [11,12]. A third set has evaluated the impacts of WER management on the 
environmental, financial and social performance of manufacturers [13,14]. A fourth group of studies has focused on the barriers and drivers of successful implementation of environmental initiatives [15-17]. Although many important aspects of WER management have been covered in the literature, a closer investigation of the previous studies reveals several gaps. First, the impacts of environmental factors on the extent of WER management have not been ascertained. Previous studies have shown that environmental factors such as environmental regulations, customer pressure, social responsibility, and environmental uncertainty have a significant role in the environmental initiatives of manufacturing firms $[17,18]$. However, no study on the potential relationship between these factors and the extent of WER management is reported in the literature. To address this gap, the impacts of environmental factors on WER management of large manufacturing firms were investigated in this study. The focus of the study is on environmental factors as, for large firms, internal barriers, such as lack of financial and human resources are not serious obstacles to WER management [18]. Second, several studies have shown the benefits of waste management and reductions in the use of energy and resources for the environmental, social, and financial performance of firms. However, they tested the direct impacts of each separate WER management practice on aspects of performance $[19,20]$. For example, Iwata and Okada [20] showed that greenhouse gas reduction has a positive effect on long-term financial performance. To the best of our knowledge, no study has tested the effects of overall WER management as a second-order construct on overall sustainable performance. Testing the relationship between WER management and sustainable performance as second-order constructs extends the literature by answering the question "Do WER management practices overall lead to sustainable performance?" As firms are now obliged to make efforts to balance their economic, environmental, and social performance [21], it is important to understand the factors that can affect overall sustainable performance. Furthermore, most studies have focused on the financial and environmental outcomes of WER management $[19,20]$ and a study on social outcomes of WER management is lacking. Previous studies have shown that problems in companies' social practices have negative effects on their financial performance (FP) [21,22]. To address these gaps, this study develops reflective-formative second-order constructs of both WER management and sustainable performance as core competencies of firms and investigates the relationship between them.

The findings of this study will contribute to the literature on WER management in three ways. First, multidimensional formative scales are developed to measure overall WER management as an integrated single construct. Second, the impacts of environmental factors on the extent of manufacturing firms' WER management are investigated. Third, the relationship between overall WER management and sustainable performance is evaluated. The results can guide policymakers seeking to promote WER management practices among manufacturing firms. Furthermore, understanding the impacts of WER management on sustainable performance will help the managers of manufacturing firms to realize that WER management overall will improve the performance of firms $[7,8]$.

\section{Literature Review}

\subsection{Waste, Energy, and Resource Management}

Brundtland [23] defines sustainability as "meeting the needs of the present generation without compromising the ability of future generations to meet their own needs" (p. 8). The definition of sustainability ranges from an inter-generational philosophical stance to a multi-dimensional and multi-scale term. The impacts of decisions on future generations are the focus of the inter-generational philosophical stance. The multi-dimensional focus includes topics related to the 'triple-bottom-line' of balancing corporate social responsibility, including balancing economic, environmental, and social dimensions of sustainability [24]. In this study, sustainable performance refers to the economic, environmental, and social performance of firms. Economic performance refers to elements, such as cost reduction and productivity, market share, and profitability enhancement [25]. Environmental performance refers to reduction in hazardous materials consumption, waste generation, 
energy consumption, and material usage and compliance with environmental regulations [25]. Social performance refers to the ability of the firm to meet or exceed stakeholder expectations regarding social issues and consequently to enhance the firm's image in the eyes of the general public and employees [25].

Daly [26] introduced three rules that must be met in order to be sustainable: (1) the extraction or harvest rates of resources should not exceed their regeneration rates, (2) waste and emission generation rates should not exceed the natural absorption capacities of the ecosystem, and (3) absorption and regenerative capacities are natural capital, and an inability to keep these capacities represents consumption of this natural capital which is not sustainable. Today, overall, none of these rules are being met and humans use energy and resources and produce waste at rates that are greater than the planet's natural regeneration and absorption capacities, causing environmental issues such as global warming and ozone depletion. As such, substantial improvements in the efficiency of energy and resource use as well as reductions in waste and emission generation are needed [10]. WER management is one of the ways to achieve sustainability $[7,8]$. Significant amounts of energy and resources are consumed in manufacturing and significant amounts of waste are produced [6]. As such, there is a need for manufacturers to change their processes and incorporate WER management in all of their operations. The WER management concept was modelled as a second-order composite in this study, which comprised waste management, energy management and resource management. Waste management refers to practices that aim to reduce material consumption and waste production, such as aspect-impact analysis, the $4 \mathrm{R}$ program (reduce, reuse, recycle, and recover), and product life cycle analysis [25]. Energy management refers to practices that aim to reduce energy consumption and its impact on the environment, such as energy conservation programs, regular energy audit, using energy efficient equipment, and using renewable energy [25]. Resource management refers to practices that aim to optimize resource usage, such as giving priority to recyclable, repairable, reusable, renewable, and biodegradable products, regular reviews of the process flow, and implementing a paperless policy [25].

Integrating WER management into manufacturing sectors is not a new concept. Kurdve et al. [27] studied the tactics and models which help manufacturers to integrate WER management into their operations. Some studies have combined the concepts of WER management and other manufacturing practices, such as lean manufacturing [10,28]. However, few studies have investigated the impacts of environmental factors on the extent of WER management and also the impacts of WER management on sustainable performance. Sustainability has three pillars, namely economic, environmental, and social. As such, achieving sustainable performance requires implementing practices that lead to better economic, environmental and social performance. Economic performance is the most important driver for firms, especially in developing countries, in implementing environmentally friendly practices [29]. Nonetheless, it has been reported that environmental practices can provide competitive advantage, enhance brand reputation, reduce energy, and resource consumption and cost and reduce waste, and consequently lead to better economic performance in the long-term [18,30]. Furthermore, environmental practices can stimulate firms to meet their social responsibilities [31].

\subsection{Institutional Theory}

Institutional theory, proposed by North [32], suggests that three external isomorphic factors - coercive, normative and mimetic [33,34] — create pressures on firms and drive their decisions and practices. Coercive pressure refers "to both formal and informal political and regulatory influence from government or other powerful organisations or the society" [35]. Scott [34] stated that coercive pressures push companies to implement a specific management practice. Failing to respond to this pressure can jeopardize a firm's legitimacy. Normative pressure refers to "recognised standards that dictate what behaviours are acceptable in various sectors of activity, such as the values and norms held by professional associations" [36]. Mimetic pressure refers "to a specific behaviour in an organization's market and the perceived success of competing organizations that have already adopted it" [37]. 
Previous studies have shown that decisions to adopt and implement environmental initiatives are highly affected by isomorphic pressures $[17,18]$. In the light of institutional theory and literature, the present study evaluates the impacts of five isomorphic pressures, namely environmental regulatory pressure, customer pressure, environmental uncertainty, expected business benefits, and social responsibility, on shaping the WER management practices of manufacturing firms.

The term 'regulation' in the present context refers to environmental procedures and rules that are imposed on firms by the government and regulatory institutions to push them to implement environmental initiatives such as WER management [18,38]. Regulation is a commonly cited driver of firms' environmental practices [17,18,39], as is customer pressure [18,40]. According to Han et al. [41] and Han and Hwang [42], as customers are increasingly aware of environmental issues, they impose ever greater pressure on firms to be responsible for the impacts of their activities on the environment. A previous study introduced environmental uncertainty as another driver of environmental practices $[43,44]$. Environmental uncertainty refers to the unpredictable and frequent changes in competitor behaviour, technological development, and customer preferences perceived by the managers of a firm [44]. The uncertain business environment pushes firms to be more proactive than firms in less turbulent environments [43]. Expected business benefits is another isomorphic pressure that researchers have found to be an important driver of environmental practices [18,40]. The expected business benefits of implementing environmental practices can be either financial or non-financial, and include, for example, enhancement of the firm's reputation, cost reductions and revenue increases [45]. Finally, social responsibility is a kind of normative pressure [34] that, according to the literature, has a substantial effect on firms' decision to implement environmental practices [46,47]. Social responsibility refers to "an organization's sense of responsibility that is voluntarily held by that organization towards the society and results in its motivations to consider and pursue that particular society's welfare" [18].

\section{Conceptualization and Hypotheses Development}

Based on the review of the literature on the drivers of green practices and institutional theory [48], environmental regulatory pressure, customer pressure, environmental uncertainty, expected business benefits, and social responsibility are proposed as environmental factors that may shape a manufacturing firm's extent of WER management and consequently its sustainable performance (Figure 1). In the following subsections, the hypotheses are developed and supported.

\subsection{Environmental Regulatory Pressure}

Regulations are considered as coercive mechanisms that impose pressure on firms to perform specific practices [34]. These regulations, standards and rules that include elements of imposition and inducement may come from government, parent companies as well as international organizations. Previous studies have shown that regulatory pressures are the most powerful factor to motivate firms to implement environmental practices and be responsible for the effects of their activities on the environment [48]. Cheng et al. [49] asserted that environmental regulatory pressure is the main driver of firms' decision to adopt environmental practices in their activities. Testa et al. [50] found that regulatory pressures force firms to reduce their environmental impact and improve their energy efficiency. In the context of climate change, it is expected that environmental regulations will become more stringent and firms will face greater pressure to comply with environmental good practice (e.g., reduce material consumption, implement an energy conservation programme, optimize resource usage and have specific objectives for waste management). This will not only help them to meet the requirements of regulations but will also give them competitive advantage. Therefore, it is proposed that environmental regulatory pressures affect the extent of WER management of firms. Thus, we hypothesize that:

H1: Environmental regulatory pressure is positively related to the extent of firms' WER management. 


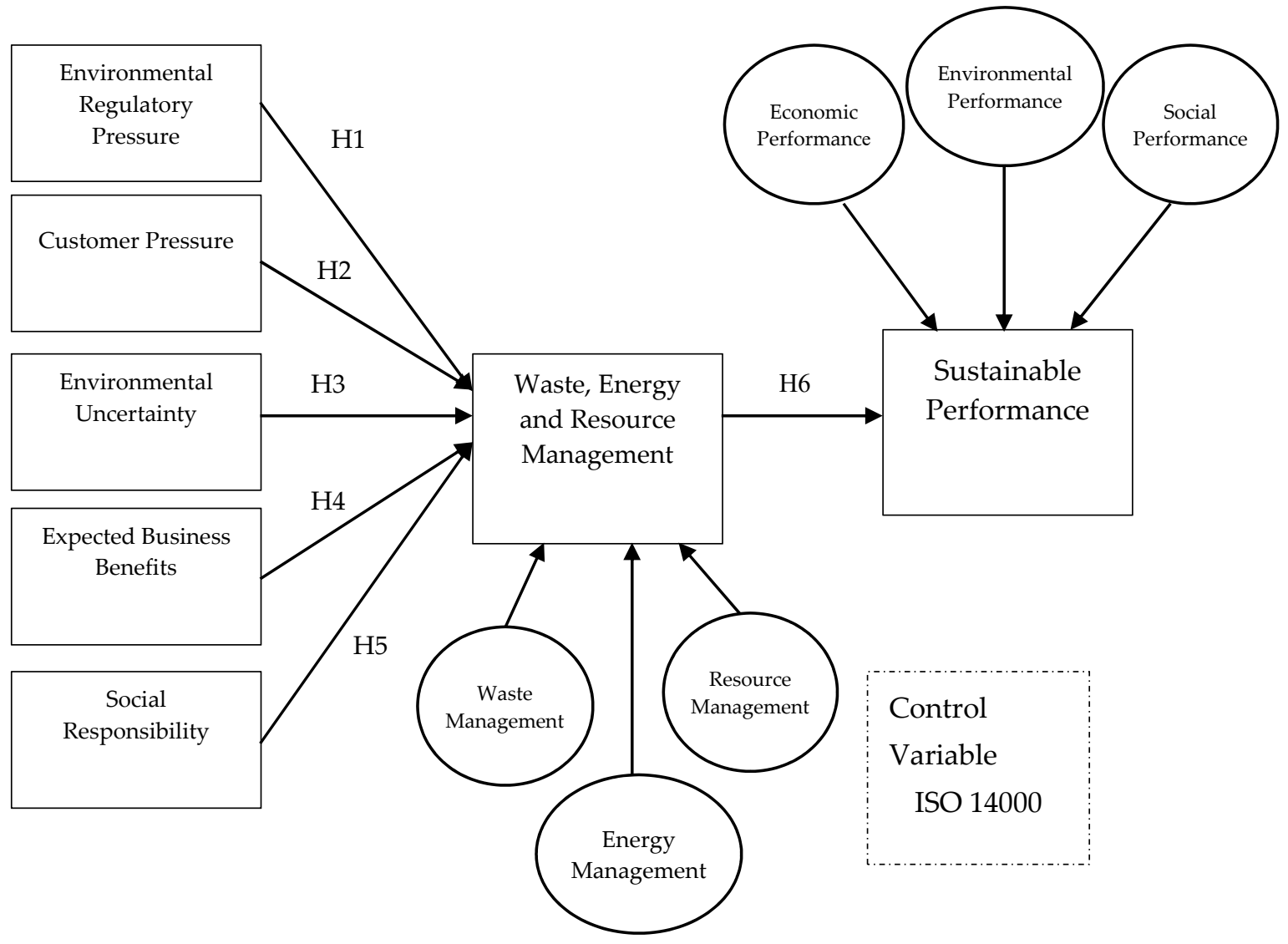

Figure 1. Conceptual framework.

\subsection{Customer Pressure}

Customers are the main financial stakeholders of firms and have the power to exert considerable pressure on them to behave in an environmentally friendly manner [51]. Previous studies have shown that firms face increasing pressure from their customers to implement environmental management [50-52]. Indeed, companies understand the importance of responding to customer requests in creating a competitive advantage. As such, the shift in costumers' awareness of environmental issues and consequently their demand for the impacts on the environment of operations and products to be minimized is capturing the attention of firms and stimulating them to consider their environmental practices [53]. Customers have power, and they can decide whether, when and how to use that power to impact on firms' decisions and activities. This power can explain why customer pressure has frequently been identified as an important stimulus of firms' environmental practices [54]. Accordingly, the literature finds industrial customers' pressure is one of the most critical factors in the choice to use expensive recycled materials and to adopt environmental certification [55]. In addition, customer pressure has been shown to cause firms to implement eco-design initiatives [18]. Accordingly, we propose the following hypothesis:

H2: Customer pressure is positively related to the extent of firms' WER management.

\subsection{Environmental Uncertainty}

Environmental uncertainty has been found to be one of the key determinants of environmental practices in previous studies [56]. Many factors, such as competitors, technology, distributors, and customers, are the sources of environmental uncertainty [57]. Li and Atuahene-Gima [58] found environmental uncertainty to be the most important driver of firms' decision to adopt environmental practices. It also was an important factor in shaping corporate environmental strategy in Wu's [57] study. 
In uncertain business environments, managers tend to be more innovative and proactive than they are in less turbulent environments. Managers of firms will attempt to gather and process more information under conditions of high environmental uncertainty, to address environmental changes [44], and also tend to be more innovative in creating value, which is a competitive advantage [59]. Furthermore, López-Gamero et al. [60] indicate that environmental practices can be of long-term benefit for firms even in an unstable business environment. This is supported by Jangga et al. [61], who stated that when managers believe a practice can bring a unique competitive advantage in the context of an unpredictable future, they are willing to risk being proactive. Lin and Ho [44] asserted that companies are more likely to implement environmental practices to enhance their environmental performance in uncertain environments. Thus, we expect that environmental uncertainty positively affects the extent of WER management practices and suggest the following hypothesis:

H3: Environmental uncertainty is positively related to the extent of firms' WER management.

\subsection{Expected Business Benefits}

Expected business benefits refer to "anticipation in financial gains and operational benefits from strategic positioning in practice" [17]. It is well established that financial returns and making profit are the main objectives of a firm. In this sense, every decision is assessed on cost-benefit criteria. Managing resources and capabilities is expected to comply with this general rule; that is, a firm needs to expect business benefits from managing capabilities and resources before it will implement this strategy. Therefore, firms manage their resources and capabilities to reduce their environmental impact if they can get business benefits in return. Accordingly, it is hypothesized that:

H4: Expected business benefit is positively related to the extent of firms' WER management.

\subsection{Social Responsibility}

Social responsibility indicates that corporations have an ethical responsibility to treat the public and the environment with dignity and respect. As stated by Jones [62], to be in agreement with the expectations and norms of a society through which a firm's behaviours are determined, that firm is likely to perceive that it needs a voluntary commitment to the community. Accordingly, Lee et al. [63] asserted that social expectation was an important driver of environmental practice. Moreover, research by Iranmanesh et al. [18] found that social responsibility has a significant effect on firms' decision to adopt eco-design initiatives in both developing and developed countries. Therefore, we expect that, in order to fulfil their social responsibility, firms will implement environmental practices such as reducing energy waste and carbon dioxide emissions (which will also have the benefit of maximizing productivity) and also reduce their use of resources to lessen the impact on future generations. On this basis, we propose the following hypothesis:

H5: Social responsibility is positively related to the extent of firms' WER management.

\subsection{WER Management}

The impacts of WER management on the sustainable performance of firms have been shown in many studies [64,65]. According to Azevedo et al. [66] and Iranmanesh et al. [18], environmental practices not only contribute to sustainability but also can positively affect economic performance and social performance. Environmental practices can yield significant gain for firms in the form of cost savings through reductions in material, energy, and waste, savings in operational costs and from environmental penalties that have been avoided, an improved reputation, better customer attraction and retention, and greater competitive value [67]. A survey by the Economist Intelligence Unit found that "... $69 \%$ of managers believe the relationship between financial performance and a commitment to sustainability is strong in the long term (5-10 years), and companies worldwide are 
moving sustainability principles into their core policies and practices" [10]. Based on the literature, the following hypothesis was developed:

H6: The extent of WER management has a positive effect on the sustainable performance of manufacturing firms.

\subsection{ISO 14000 as a Control Variable}

The ISO 14000 series was developed by the International Organization for Standardization (ISO) in 1996 to provide the requirements for an effective environmental management system (EMS). The ISO 14000 series consists of 21 standards and guidance documents. These environmental standards are divided into six categories, namely "(1) environmental management system; (2) environmental auditing; (3) environmental performance evaluation; (4) environmental labeling; (5) life-cycle assessment; and 6) environmental aspects in product standards" [68]. Among these standards, ISO 14001 is the only one designed for the purpose of audit. The core elements of the ISO 14001 standard are "environmental policy, planning, implementation and operation, checking and corrective action, review, and improvement" [69]. Previous studies have shown that ISO 14001 can reduce waste generation [70], resource use [71], and energy consumption [72]. According to Rondinelli and Vastag [73], ISO 14001 certification leads to more ideas among employees for recycling of materials and increases their commitment to recycle. As such, in this study, having ISO 14000 certification was considered as a control variable to control its effect on the relationship between environmental factors and WER management.

\section{Methodology}

\subsection{Measurement of Constructs}

A structured questionnaire was used in this study to collect data from managers of large manufacturing firms and test the developed hypotheses. The items for the constructs were adapted from previous studies to ensure content validity and measured on five-point Likert scales ranging from "strongly disagree" to "strongly agree" (see Supplementary Materials). The items for environmental regulatory pressure, customer pressure, expected business benefits and social responsibility were adapted from Iranmanesh et al. [18]. The scale for environmental uncertainty were adapted from Lin and Ho [44]. The items for WER management and sustainable performance were adapted from Jin and Zailani [25] and Zailani et al. [74].

\subsection{Sample and Data Collection}

The sampling frame of this study comprises all large manufacturing firms in Malaysia. Large manufacturing firms were selected as they are sensitive to environmental issues and are pressured by government, non-government organizations and customers to act in a sustainable manner [75,76]. In Malaysia, large manufacturing firms refer to companies with more than 200 full-time employees [77]. The sampling list was obtained from the 2017 directory of the Federation of Malaysian Manufacturers (FMM) [78], which lists over 700 large manufacturing firms. The data were collected through mail and, due to the typically low response rate to mail surveys [79] and the small sampling frame of this study, the questionnaire was sent to all firms.

This study targeted CEOs, general managers, managing directors, directors, managers or persons-in-charge of environmental health and safety departments in manufacturing firms. These people were selected as they have knowledge about WER management practices and the performance of their firms [18]. The questionnaire was posted to the corresponding respondents in each firm. Out of 714 distributed questionnaires, after two reminders via telephone calls, 173 usable sets of data were collected (a response rate of 24.2\%). Based on G-Power, this sample has enough power (power of 0.985 at significance level of 0.05 ) to test the model of this study $[80,81]$. To guarantee the representativeness of the responses obtained, the possibility of non-response bias was examined [82] via 
comparison between the early respondents (those responding within a month) and the late respondents (among the last). The results suggested a lack of difference between early and late respondents (at the 5\% significance level), indicating that non-response bias was not an issue in the current research. The majority of the firms that participated in this study were from the electrical and electronics industry (29.5\%), had 201-500 employees (38.2\%), had been established for more than 15 years ( $76.3 \%)$, had ISO 14000 certification $(79.2 \%)$ and ISO 9000 certification (90.8\%), and were fully foreign owned $(49.7 \%)$.

\subsection{Data Analysis}

To test the research model, we used structural equation modelling (SEM) using partial least squares (PLS) with SmartPLS 3.0 software [83]. PLS was chosen in preference to the covariance-based SEM (CB-SEM) technique for this study, since PLS is designed for both formative and reflective constructs, whereas in CB-SEM constructs and indicators should be modelled reflectively [84]. Also, PLS is appropriate for recognizing the key driver variables, which matches the objective of this research. Based on Anderson and Gerbing's [85] suggestion, this study followed a two-step analytical approach in which the measurement model was tested first, followed by the hypothesized relationships [86,87].

\section{Results}

\subsection{Measurement Model Results}

Table 1 shows that the loading of all items pertaining to the first-order constructs are higher than 0.70 [88], and the average variance extracted (AVE) of all the constructs are higher than 0.50 [88]. This indicates an acceptable level of convergent validity for the measurement model [89-91]. Furthermore, the constructs' reliability was established, as the composite reliability of all constructs exceeded the suggested value of 0.70 [88].

Table 1. Measurement model.

\begin{tabular}{ccccc}
\hline Constructs & No. of Items & Factor Loadings & CR & AVE \\
\hline Environmental Regulatory & 6 & $0.729-0.825$ & 0.897 & 0.592 \\
Pressure & 6 & $0.718-0.845$ & 0.919 & 0.655 \\
Customer Pressure & 4 & $0.761-0.857$ & 0.894 & 0.678 \\
Environmental Uncertainty & 9 & $0.723-0.833$ & 0.925 & 0.577 \\
Expected Business Benefits & 9 & $0.739-0.929$ & 0.959 & 0.724 \\
Social Responsibility & 5 & $0.750-0.902$ & 0.928 & 0.723 \\
Energy Management & 5 & $0.793-0.848$ & 0.906 & 0.660 \\
Waste Management & 5 & $0.705-0.896$ & 0.904 & 0.655 \\
Resource Management & 9 & $0.722-0.879$ & 0.943 & 0.650 \\
Economic Performance & 7 & $0.871-0.902$ & 0.973 & 0.839 \\
Environmental Performance & 6 & $0.881-0.937$ & 0.958 & 0.790 \\
Social Performance & &
\end{tabular}

Note: $C R$ composite reliability, $A V E$ average variance extracted.

The heterotrait-monotrait ratio of correlations (HTMT) was tested to assess discriminant validity [88]. The HTMT ratio should be lower than 0.85 to establish discriminant validity [92]. Table 2 shows that all the values passed $\mathrm{HTMT}_{0.85}$, indicating that the discriminant validity was fulfilled for our constructs [93].

The constructs of sustainable performance and WER management were then modelled as formative second-order constructs. WER management is, thus, a single measure reflecting a company's overall management of waste, energy, and resources, while sustainable performance is a single measure capturing economic performance, social performance and environmental performance. A two-stage approach recommended by Becker et al. [94] was applied to create these second-order constructs. In the first step, we assessed multicollinearity by computing the variance inflation factor (VIF) of the first-order constructs. Table 3 shows that the VIF value of each of the underlying constructs does not 
exceed the recommended limit of 5 [82]. This means that there was no multicollinearity issue for the second-order constructs (namely sustainable performance and WER management).

Table 2. Discriminant validity $\left(\mathrm{HTMT}_{0.85}\right)$.

\begin{tabular}{|c|c|c|c|c|c|c|c|c|c|c|c|}
\hline Constructs & ERP & $\mathrm{CP}$ & EU & EBB & SR & WM & EM & RM & EP & ENP & SP \\
\hline \multicolumn{12}{|l|}{ ERP } \\
\hline $\mathrm{CP}$ & 0.613 & & & & & & & & & & \\
\hline EU & 0.625 & 0.699 & & & & & & & & & \\
\hline EBB & 0.674 & 0.625 & 0.633 & & & & & & & & \\
\hline SR & 0.451 & 0.756 & 0.554 & 0.502 & & & & & & & \\
\hline WM & 0.574 & 0.610 & 0.607 & 0.548 & 0.437 & & & & & & \\
\hline EM & 0.556 & 0.537 & 0.502 & 0.391 & 0.359 & 0.794 & & & & & \\
\hline RM & 0.309 & 0.446 & 0.474 & 0.304 & 0.173 & 0.692 & 0.719 & & & & \\
\hline EP & 0.410 & 0.532 & 0.454 & 0.391 & 0.409 & 0.697 & 0.628 & 0.548 & & & \\
\hline ENP & 0.532 & 0.498 & 0.609 & 0.402 & 0.309 & 0.738 & 0.702 & 0.591 & 0.765 & & \\
\hline SP & 0.398 & 0.577 & 0.646 & 0.395 & 0.404 & 0.598 & 0.629 & 0.604 & 0.606 & 0.771 & \\
\hline
\end{tabular}

Notes: ERP, environmental regulatory pressure; CP, customer pressure; EU, environmental uncertainty; EBB, expected business benefits; SR, social responsibility; WM, waste management; EM, energy management; RM, resource management; EP, economic performance; ENP, environmental performance; SP, social performance.

Next, we established the significance of the relationship between each second-order construct and its first-order constructs [88]. As shown in Table 3, all first-order dimensions were found to make a significant contribution to the corresponding second-order constructs.

Table 3. Evaluation of the second-order constructs.

\begin{tabular}{llllll}
\hline Second-Order Constructs & First-Order Constructs & Measure & Weights & $\boldsymbol{t}$-Value & VIF \\
\hline Waste, Energy, and & Waste Management & Formative & 0.377 & 3.742 & 2.560 \\
Resource Management & Energy Management & Formative & 0.414 & 4.376 & 2.721 \\
& Resource Management & Formative & 0.341 & 4.278 & 2.252 \\
Sustainable Performance & Economic Performance & Formative & 0.392 & 3.485 & 2.369 \\
& Social Performance & Formative & 0.306 & 2.914 & 2.329 \\
& Environmental & Formative & 0.422 & 5.870 & 3.555 \\
& Performance & & & & \\
\hline
\end{tabular}

\subsection{Assessment of the Structural Model}

The structural model was assessed first by determining the R-square $\left(R^{2}\right)$ measure of the endogenous constructs and the path coefficient [95]. Environmental regulatory pressure, customer pressure, environmental uncertainty, expected business benefits, and social responsibility explain $39.7 \%$ of WER management $\left(R^{2}=0.397\right)$. Moreover, the construct of WER management predicts $57.6 \%$ of sustainable performance $\left(R^{2}=0.576\right)$. By incorporating Stone-Geisser's $Q^{2}$, we tested the predictive capacity of the model [96-98]. A value greater than zero for $\mathrm{Q}^{2}$ indicates that the model has acceptable predictive relevance [99]. A value of 0.356 was obtained for WER management, and a value of 0.564 for sustainable performance.

To analyse the structural model, we applied non-parametric bootstrapping with 5000 replications [88]. Environmental regulatory pressure $(\beta=0.190 ; p<0.01)$, customer pressure $(\beta=0.245$; $p<0.01)$, environmental uncertainty $(\beta=0.201 ; p<0.01)$, and expected business benefits $(\beta=0.144$; $p<0.01$ ) all had a significant effect on WER management among the large companies, but social responsibility $(\beta=-0.030 ; p>0.05)$ was not a significant predictor of WER management. Furthermore, WER management $(\beta=0.759 ; p<0.01)$ had a significant effect on sustainable performance. Thus, H1, $\mathrm{H} 2, \mathrm{H} 3, \mathrm{H} 4$, and $\mathrm{H} 6$ were supported, while $\mathrm{H} 5$ was not (Table 4, Figure 2). 
Table 4. Hypotheses testing.

\begin{tabular}{|c|c|c|c|c|c|c|}
\hline Hypotheses & Relationships & Beta & t-Value & Decision & $\mathrm{Q}^{2}$ & $\mathbf{R}^{2}$ \\
\hline H1 & $\mathrm{REP} \rightarrow \mathrm{WERM}$ & 0.190 & $3.449 * *$ & Supported & 0.356 & 0.397 \\
\hline H2 & $\mathrm{CP} \rightarrow \mathrm{WERM}$ & 0.245 & $4.526^{* *}$ & Supported & & \\
\hline H3 & $\mathrm{EU} \rightarrow \mathrm{WERM}$ & 0.201 & $4.278^{* *}$ & Supported & & \\
\hline H4 & EBB $\rightarrow$ WERM & 0.144 & $2.753^{* *}$ & Supported & & \\
\hline H5 & $\mathrm{SR} \rightarrow \mathrm{WERM}$ & -0.030 & 0.320 & Not Supported & & \\
\hline H6 & $\mathrm{WERM} \rightarrow \mathrm{SP}$ & 0.759 & $18.982^{* *}$ & Supported & 0.564 & 0.576 \\
\hline \multicolumn{7}{|c|}{ Control Variable: ISO 14000} \\
\hline - & ISO 14000 & 0.110 & 1.954 * & - & - & - \\
\hline
\end{tabular}

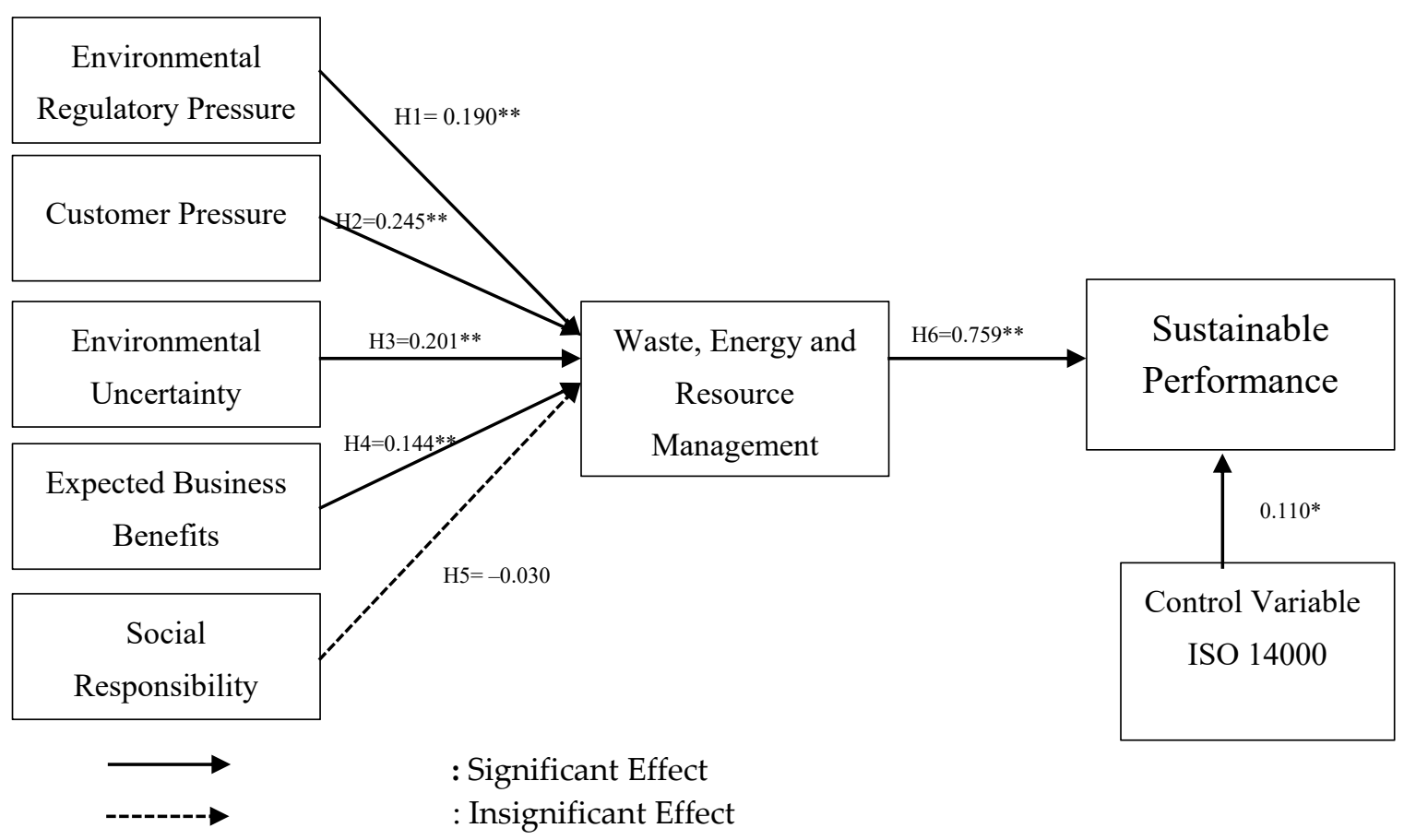

Figure 2. Structural model. Notes: ${ }^{* *} p<0.01 .{ }^{*} p<0.05$.

\section{Discussion and Implications}

Significant amounts of energy and resources are consumed by the manufacturing sector and significant amounts of waste are generated. Indeed, the manufacturing sector is one of the main contributors to global environmental problems. This study investigates the environmental drivers of WER management practices and the effect of those practices, in turn, on sustainable performance. The results suggest that the extent of WER management is affected by environmental regulatory pressure, customer pressure, environmental uncertainty, and expected business benefits, and WER management, in turn, has a significant effect on the sustainable performance of manufacturing firms. The impact of social responsibility on WER management is not supported.

According to the results, environmental regulatory pressure and customer pressure have positive effects on the extent of WER management, which is consistent with the findings of Iranmanesh et al. [18] and Zailani et al. [17], who found that stringent environmental regulations and greater customer pressure may promote the implementation of environmental practices. This suggests greater environmental regulatory pressure and customer pressure may promote the adoption of WER management practices. Given that Malaysian customers' and the Malaysian government's concerns about environmental issues have increased dramatically [17], the government of Malaysia should regulate the generation and disposal of waste, as well as resource and energy consumption, and should plan to enhance 
customers' awareness of environmental issues and the impacts of manufacturing firms' activities on the environment. In addition, with the increasing price of energy and raw materials and also waste disposal costs [6], the effective management of resource and energy consumption and waste generation will have an important effect on the price of an end product. As such, manufacturing firms should manage WER to keep the price of their products competitive.

The results also confirm the significant role of environmental uncertainty in shaping the decision of manufacturing firms to implement WER management practices. This is consistent with the finding of Zailani et al. [43] and Latan et al. [100] that managers facing uncertain business environments tend to be more proactive. Manufacturing firms are currently facing environmental uncertainty with regard to customer preferences and competitor behaviours. WER management practices are types of environmental practices that can help firms to save costs and, as such, can help firms to meet potential customers' environmental requests and be proactive without the need for large amounts of investment. Furthermore, the results indicate that expected business benefits have a positive significant effect on the extent of WER management practices, which is in line with the findings of Iranmanesh et al. [18] and Eltayeb et al. [47]. However, in the present study, social responsibility has no effect on implementing WER management practices, which is not consistent with the findings of Lee et al. [63]. Our findings suggest that manufacturing firms in Malaysia will choose to be proactive and implement WER management practices only if they expect their profitability to increase as a result-rather than to fulfil a set of social or ethical values.

In terms of the theoretical contribution, to the best of our knowledge, this study is the first attempt to assess WER management as an integrated higher-order formative construct comprising waste management, energy management and resource management. Furthermore, this is the first time the overall impact of WER management on the sustainable performance of manufacturing firms has been investigated. The result indicates that WER management can lead to sustainable performance. Furthermore, the environmental drivers of WER management were investigated and the results suggest that environmental regulatory pressure, customer pressure, environmental uncertainty and expected business benefits are factors that affect the decision of managers to practise WER management. The results of the study also provide several implications for the managers of manufacturing companies as well as policymakers. Understanding the environmental factors that motivate manufacturing firms to implement WER management practices will help policymakers to adjust policies and strategies in ways that will promote WER practices among firms and consequently reduce the use of energy and resources and waste generation. Additionally, the significant effect of WER practices on sustainable performance will help managers of manufacturing firms to convince shareholders to invest in WER management.

\section{Limitations and Future Studies}

Although the objectives of the study were addressed, there are certain limitations that should be considered before generalizing the findings and these limitations can also be a starting point for future studies. First, as the data were collected from large manufacturing firms, the results may not be applicable to small and medium enterprises (SME). Further research is needed on SMEs. Second, a future study could consider internal factors, such as top management support and the quality of the firm's human resources. Third, the study data were limited to Malaysia. Further studies are needed to test the model on other countries, developed as well as developing ones.

Supplementary Materials: The following are available online at http://www.mdpi.com/2071-1050/11/8/2443/s1.

Author Contributions: S.Z. contributed to data collection; M.I., B.F. and M.H.A. analyzed the data and wrote the article.

Funding: This research was funded by Faculty of Economics and Management, Universiti Kebangsaan Malaysia, grant number FEP1.

Conflicts of Interest: The authors declare no conflict of interest. 


\section{References}

1. Le Heron, R.; Hayter, R. Paths of Sustainable Industrialization in the Knowledge-based Economy. In Knowledge, Industry and Environment: Institutions and Innovation in Territorial Perspective; Hayter, R., Le Heron, R., Eds.; Routledge: Abingdon, UK, 2018; pp. 49-66.

2. Duflou, J.R.; Sutherland, J.W.; Dornfeld, D.; Herrmann, C.; Jeswiet, J.; Kara, S.; Hauschild, M.; Kellens, K. Towards energy and resource efficient manufacturing: A processes and systems approach. CIRP Ann. Technol. 2012, 61, 587-609. [CrossRef]

3. Leonidou, L.C.; Christodoulides, P.; Thwaites, D. External Determinants and Financial Outcomes of an Eco-friendly Orientation in Smaller Manufacturing Firms. J. Small Bus. Manag. 2016, 54, 5-25. [CrossRef]

4. Eltayeb, T.K.; Zailani, S.; Ramayah, T. Green supply chain initiatives among certified companies in Malaysia and environmental sustainability: Investigating the outcomes. Resour. Conserv. Recycl. 2011, 55, 495-506.

5. Zailani, S.; Iranmanesh, M.; Sean Hyun, S.; Ali, M.H. Barriers of Biodiesel Adoption by Transportation Companies: A Case of Malaysian Transportation Industry. Sustainability 2019, 11, 931. [CrossRef]

6. Ball, P.D.; Evans, S.; Levers, A.; Ellison, D. Zero carbon manufacturing facility-Towards integrating material, energy, and waste process flows. Proc. Inst. Mech. Eng. Part B J. Eng. Manuf. 2009, 223, 1085-1096. [CrossRef]

7. Cremiato, R.; Mastellone, M.L.; Tagliaferri, C.; Zaccariello, L.; Lettieri, P. Environmental impact of municipal solid waste management using Life Cycle Assessment: The effect of anaerobic digestion, materials recovery and secondary fuels production. Renew. Energy 2018, 124, 180-188. [CrossRef]

8. Taelman, S.; Tonini, D.; Wandl, A.; Dewulf, J. A holistic sustainability framework for waste management in European cities: Concept development. Sustainability 2018, 10, 2184. [CrossRef]

9. Kishawy, H.; Hegab, H.; Saad, E. Design for Sustainable Manufacturing: Approach, Implementation, and Assessment. Sustainability 2018, 10, 3604. [CrossRef]

10. Smith, L.; Ball, P. Steps towards sustainable manufacturing through modelling material, energy and waste flows. Int. J. Prod. Econ. 2012, 140, 227-238. [CrossRef]

11. D'Adamo, I.; Rosa, P.; Terzi, S. Challenges in waste electrical and electronic equipment management: A profitability assessment in three European countries. Sustainability 2016, 8, 633. [CrossRef]

12. Merkert, L.; Harjunkoski, I.; Isaksson, A.; Säynevirta, S.; Saarela, A.; Sand, G. Scheduling and energy-Industrial challenges and opportunities. Comput. Chem. Eng. 2015, 72, 183-198. [CrossRef]

13. Adebambo, H.O.; Ashari, H.; Nordin, N. An Empirical Study on the Influence of Sustainable Environmental Manufacturing Practice on Firm Performance. J. Sustain. Sci. Manag. 2015, 10, 42-51.

14. Abdul-Rashid, S.H.; Sakundarini, N.; Raja Ghazilla, R.A.; Thurasamy, R. The impact of sustainable manufacturing practices on sustainability performance: Empirical evidence from Malaysia. Int. J. Oper. Prod. Manag. 2017, 37, 182-204. [CrossRef]

15. Tot, B.; Srđević, B.; Vujić, B.; Russo, M.A.T.; Vujić, G. Evaluation of key driver categories influencing sustainable waste management development with the analytic hierarchy process (AHP): Serbia example. Waste Manag. Res. 2016, 34, 740-747. [CrossRef]

16. Abdullah, M.; Zailani, S.; Iranmanesh, M.; Jayaraman, K. Barriers to green innovation initiatives among manufacturers: The Malaysian case. Rev. Manag. Sci. 2016, 10, 683-709. [CrossRef]

17. Zailani, S.; Govindan, K.; Iranmanesh, M.; Shaharudin, M.R.; Chong, Y.S. Green innovation adoption in automotive supply chain: The Malaysian case. J. Clean. Prod. 2015, 108, 1115-1122. [CrossRef]

18. Iranmanesh, M.; Fayezi, S.; Hanim, S.; Hyun, S.S. Drivers and outcomes of eco-design initiatives: A cross-country study of Malaysia and Australia. Rev. Manag. Sci. 2018, 1-22. [CrossRef]

19. Ding, Z.; Yi, G.; Tam, V.W.Y.; Huang, T. A system dynamics-based environmental performance simulation of construction waste reduction management in China. Waste Manag. 2016, 51, 130-141. [CrossRef]

20. Iwata, H.; Okada, K. How does environmental performance affect financial performance? Evidence from Japanese manufacturing firms. Ecol. Econ. 2011, 70, 1691-1700. [CrossRef]

21. Zaid, A.A.; Jaaron, A.A.M.; Bon, A.T. The impact of green human resource management and green supply chain management practices on sustainable performance: An empirical study. J. Clean. Prod. 2018, 204, 965-979. [CrossRef]

22. DiSegni, D.M.; Huly, M.; Akron, S. Corporate social responsibility, environmental leadership and financial performance. Soc. Responsib. J. 2015, 11, 131-148. [CrossRef] 
23. Brundtland, G.H. Our Common Future; World Commission on Environment and Development: Brussels, Belgium, 1987.

24. Iranmanesh, M.; Zailani, S.; Hyun, S.S.; Ali, M.H.; Kim, K. Impact of Lean Manufacturing Practices on Firms' Sustainable Performance: Lean Culture as a Moderator. Sustainability 2019, 11, 1112. [CrossRef]

25. Jin, T.T.; Zailani, S. Antecedent and outcomes study on green value chain initiatives: A perspective from sustainable development and sustainable competitive advantage. Int. J. Value Chain Manag. 2010, 4, 319-364. [CrossRef]

26. Daly, H.E. Toward some operational principles of sustainable development. Ecol. Econ. 1990, 2, 1-6. [CrossRef]

27. Kurdve, M.; Shahbazi, S.; Wendin, M.; Bengtsson, C.; Wiktorsson, M. Waste flow mapping to improve sustainability of waste management: A case study approach. J. Clean. Prod. 2015, 98, 304-315. [CrossRef]

28. Yang, M.G.M.; Hong, P.; Modi, S.B. Impact of lean manufacturing and environmental management on business performance: An empirical study of manufacturing firms. Int. J. Prod. Econ. 2011, 129, 251-261. [CrossRef]

29. Zhu, Q.; Sarkis, J. Relationships between operational practices and performance among early adopters of green supply chain management practices in Chinese manufacturing enterprises. J. Oper. Manag. 2004, 22, 265-289. [CrossRef]

30. Jeong, E.; Jang, S.S.; Day, J.; Ha, S. The impact of eco-friendly practices on green image and customer attitudes: An investigation in a café setting. Int. J. Hosp. Manag. 2014, 41, 10-20. [CrossRef]

31. Phan, T.N.; Baird, K. The comprehensiveness of environmental management systems: The influence of institutional pressures and the impact on environmental performance. J. Environ. Manag. 2015, 160, 45-56. [CrossRef]

32. North, D. Institutions, Institutional Change and Economic Performance; Cambridge University Press: Cambridge, UK, 1990.

33. Martínez-Ferrero, J.; García-Sánchez, I.-M. Coercive, normative and mimetic isomorphism as determinants of the voluntary assurance of sustainability reports. Int. Bus. Rev. 2017, 26, 102-118. [CrossRef]

34. Scott, W.R. Institutions and Organizations, 4th ed.; Sage: Thousand Oaks, CA, USA, 2014.

35. Munir, R.; Baird, K. Influence of institutional pressures on performance measurement systems. J. Account. Organ. Chang. 2016, 12, 106-128. [CrossRef]

36. Breton, M.; Lamothe, L.; Denis, J.-L. How healthcare organisations can act as institutional entrepreneurs in a context of change. J. Health Organ. Manag. 2014, 28, 77-95. [CrossRef]

37. Messerschmidt, C.M.; Hinz, O. Explaining the adoption of grid computing: An integrated institutional theory and organizational capability approach. J. Strateg. Inf. Syst. 2013, 22, 137-156. [CrossRef]

38. Han, H.; Lee, M.J.; Kim, W. Antecedents of green loyalty in the cruise industry: Sustainable development and environmental management. Bus. Strateg. Environ. 2018, 27, 323-335. [CrossRef]

39. Awang, H.; Iranmanesh, M. Determinants and outcomes of environmental practices in Malaysian construction projects. J. Clean. Prod. 2017, 156, 345-354.

40. Zainuddin, Z.B.; Zailani, S.; Govindan, K.; Iranmanesh, M.; Amran, A. Determinants and outcome of a clean development mechanism in Malaysia. J. Clean. Prod. 2017, 142, 1979-1986. [CrossRef]

41. Han, H.; Kim, W.; Kiatkawsin, K. Emerging youth tourism: Fostering young travelers' conservation intentions. J. Travel Tour. Mark. 2017, 34, 905-918. [CrossRef]

42. Han, H.; Hwang, J. What Motivates Delegates' Conservation Behaviors While Attending a Convention? J. Travel Tour. Mark. 2017, 34, 82-98. [CrossRef]

43. Zailani, S.; Iranmanesh, M.; Nikbin, D.; Jumadi, H.B. Determinants and environmental outcome of green technology innovation adoption in the transportation industry in Malaysia. Asian J. Technol. Innov. 2014, 22, 286-301. [CrossRef]

44. Lin, C.-Y.; Ho, Y.-H. Determinants of green practice adoption for logistics companies in China. J. Bus. Ethics 2011, 98, 67-83. [CrossRef]

45. Canning, L.; Hanmer-Lloyd, S. Managing the environmental adaptation process in supplier-customer relationships. Bus. Strateg. Environ. 2001, 10, 225-237. [CrossRef]

46. Ağan, Y.; Kuzey, C.; Acar, M.F.; Açıkgöz, A. The relationships between corporate social responsibility, environmental supplier development, and firm performance. J. Clean. Prod. 2016, 112, 1872-1881. [CrossRef] 
47. ElTayeb, T.K.; Zailani, S.; Jayaraman, K. The examination on the drivers for green purchasing adoption among EMS 14001 certified companies in Malaysia. J. Manuf. Technol. Manag. 2010, 21, 206-225. [CrossRef]

48. Oliver, C. Sustainable competitive advantage: Combining institutional and resource-based views. Strateg. Manag. J. 1997, 18, 697-713. [CrossRef]

49. Cheng, H.; Hu, X.; Zhou, R. How firms select environmental behaviours in China: The framework of environmental motivations and performance. J. Clean. Prod. 2019, 208, 132-141. [CrossRef]

50. Testa, F.; Iraldo, F.; Frey, M. The effect of environmental regulation on firms' competitive performance: The case of the building \& construction sector in some EU regions. J. Environ. Manag. 2011, 92, 2136-2144.

51. Rao, P. Greening of suppliers/in-bound logistics-in the south East Asian context. In Greening the Supply Chain; Sarkis, J., Ed.; Springer: London, UK, 2006; pp. 189-204.

52. Dai, J.; Chan, H.K.; Yee, R.W.Y. Examining moderating effect of organizational culture on the relationship between market pressure and corporate environmental strategy. Ind. Mark. Manag. 2018, 74, $227-236$. [CrossRef]

53. Gualandris, J.; Kalchschmidt, M. Customer pressure and innovativeness: Their role in sustainable supply chain management. J. Purch. Supply Manag. 2014, 20, 92-103. [CrossRef]

54. Hofer, C.; Cantor, D.E.; Dai, J. The competitive determinants of a firm's environmental management activities: Evidence from US manufacturing industries. J. Oper. Manag. 2012, 30, 69-84. [CrossRef]

55. González-Benito, J.; González-Benito, Ó. A review of determinant factors of environmental proactivity. Bus. Strateg. Environ. 2006, 15, 87-102. [CrossRef]

56. Lee, S.; Klassen, R.D. Drivers and enablers that foster environmental management capabilities in small-and medium-sized suppliers in supply chains. Prod. Oper. Manag. 2008, 17, 573-586. [CrossRef]

57. Wu, G.-C. The influence of green supply chain integration and environmental uncertainty on green innovation in Taiwan's IT industry. Supply Chain Manag. Int. J. 2013, 18, 539-552. [CrossRef]

58. Maletič, M.; Maletič, D.; Gomišček, B. The role of contingency factors on the relationship between sustainability practices and organizational performance. J. Clean. Prod. 2018, 171, 423-433. [CrossRef]

59. Li, H.; Atuahene-Gima, K. The adoption of agency business activity, product innovation, and performance in Chinese technology ventures. Strateg. Manag. J. 2002, 23, 469-490. [CrossRef]

60. López-Gamero, M.D.; Molina-Azorín, J.F.; Claver-Cortés, E. Environmental uncertainty and environmental management perception: A multiple case study. J. Bus. Res. 2011, 64, 427-435. [CrossRef]

61. Jangga, R.; Ali, N.M.; Ismail, M.; Sahari, N. Effect of environmental uncertainty and supply chain flexibility towards supply chain innovation: An exploratory study. Procedia Econ. Financ. 2015, 31, 262-268. [CrossRef]

62. Jones, M.T. The institutional determinants of social responsibility. J. Bus. Ethics 1999, 20, 163-179. [CrossRef]

63. Lee, J.W.; Kim, Y.M.; Kim, Y.E. Antecedents of adopting corporate environmental responsibility and green practices. J. Bus. Ethics 2018, 148, 397-409. [CrossRef]

64. Arena, U.; Mastellone, M.L.; Perugini, F. The environmental performance of alternative solid waste management options: A life cycle assessment study. Chem. Eng. J. 2003, 96, 207-222. [CrossRef]

65. Song, Q.; Wang, Z.; Li, J. Environmental performance of municipal solid waste strategies based on LCA method: A case study of Macau. J. Clean. Prod. 2013, 57, 92-100. [CrossRef]

66. Azevedo, S.; Cudney, E.A.; Grilo, A. The Influence of Eco-Innovation Supply Chain Practices on Business Eco-Efficiency; MPRA Paper 42704; University Library of Munich: Munich, Germany, 2012.

67. Gadenne, D.L.; Kennedy, J.; McKeiver, C. An empirical study of environmental awareness and practices in SMEs. J. Bus. Ethics 2009, 84, 45-63. [CrossRef]

68. Rezaee, Z.; Elam, R. Emerging ISO 14000 environmental standards: A step-by-step implementation guide. Manag. Audit. J. 2000, 15, 60-67. [CrossRef]

69. Babakri, K.A.; Bennett, R.A.; Rao, S.; Franchetti, M. Recycling performance of firms before and after adoption of the ISO 14001 standard. J. Clean. Prod. 2004, 12, 633-637. [CrossRef]

70. Melnyk, S.A.; Sroufe, R.P.; Calantone, R.L.; Montabon, F.L. Assessing the effectiveness of US voluntary environmental programmes: An empirical study. Int. J. Prod. Res. 2002, 40, 1853-1878. [CrossRef]

71. Mohammed, M. The ISO 14001 EMS implementation process and its implications: A case study of central Japan. Environ. Manag. 2000, 25, 177-188. [CrossRef] [PubMed]

72. Gavronski, I.; Ferrer, G.; Paiva, E.L. ISO 14001 certification in Brazil: Motivations and benefits. J. Clean. Prod. 2008, 16, 87-94. [CrossRef] 
73. Rondinelli, D.; Vastag, G. Panacea, common sense, or just a label?: The value of ISO 14001 environmental management systems. Eur. Manag. J. 2000, 18, 499-510. [CrossRef]

74. Zailani, S.; Jeyaraman, K.; Vengadasan, G.; Premkumar, R. Sustainable supply chain management (SSCM) in Malaysia: A survey. Int. J. Prod. Econ. 2012, 140, 330-340. [CrossRef]

75. Tzafrir, S.S. The relationship between trust, HRM practices and firm performance. Int. J. Hum. Resour. Manag. 2005, 16, 1600-1622. [CrossRef]

76. Amran, A.; Ooi, S.K.; Mydin, R.T.; Devi, S.S. The impact of business strategies on online sustainability disclosures. Bus. Strateg. Environ. 2015, 24, 551-564. [CrossRef]

77. SMECORP Malaysia SME Corporation Malaysia-SME definition. Available online: http://www.smecorp. gov.my/index.php/en/policies/2015-12-21-09-09-49/sme-definition (accessed on 27 November 2018).

78. FMM Directory of Malaysian Industries, 48th ed.; Federation of Malaysian Manufacturers: Kuala Lumpur, Malaysia, 2017.

79. Sekaran, U.; Bougie, R. Research Methods for Business: A Skill Building Approach; John Wiley \& Sons: Hoboken, NJ, USA, 2016; ISBN 1119165555.

80. Chin, W.W. PLS-Graph User's Guide; CT Bauer Coll. Business, Univ.: Houston, TX, USA, 2001.

81. Faul, F.; Erdfelder, E.; Buchner, A.; Lang, A.-G. Statistical power analyses using G* Power 3.1: Tests for correlation and regression analyses. Behav. Res. Methods 2009, 41, 1149-1160. [CrossRef]

82. Armstrong, J.S.; Overton, T.S. Estimating nonresponse bias in mail surveys. J. Mark. Res. 1977, 14, $396-402$. [CrossRef]

83. Ringle, C.M.; Wende, S.; Becker, J.-M. SmartPLS 3; SmartPLS GmbH: Boenningstedt, UK, 2015.

84. Urbach, N.; Ahlemann, F. Structural equation modeling in information systems research using partial least squares. J. Inf. Technol. Theory Appl. 2010, 11, 5-40.

85. Anderson, J.C.; Gerbing, D.W. Structural equation modeling in practice: A review and recommended two-step approach. Psychol. Bull. 1988, 103, 411-423. [CrossRef]

86. Nikbin, D.; Iranmanesh, M.; Hyun, S.S.; Baharun, R.; Kim, I. The role of airline travelers' pre-recovery emotions during the service recovery process. J. Travel Tour. Mark. 2015, 32, 677-691. [CrossRef]

87. Weng, G.S.; Zailani, S.; Iranmanesh, M.; Hyun, S.S. Mobile taxi booking application service's continuance usage intention by users. Transp. Res. Part D Transp. Environ. 2017, 57, 207-216. [CrossRef]

88. Hair, J.F., Jr.; Hult, G.T.M.; Ringle, C.; Sarstedt, M. A Primer on Partial Least Squares Structural Equation Modeling (PLS-SEM); Sage Publications: Thousand Oaks, CA, USA, 2016; ISBN 1483377466.

89. Soltanian, M.; Zailani, S.; Iranmanesh, M.; Aziz, A.A. Motivations of SME entrepreneurs to become halalpreneurs. J. Sci. Technol. Policy Manag. 2016, 7, 173-189. [CrossRef]

90. Kurniawan, R.; Zailani, S.H.; Iranmanesh, M.; Rajagopal, P. The effects of vulnerability mitigation strategies on supply chain effectiveness: Risk culture as moderator. Supply Chain Manag. Int. J. 2017, 22, 1-15. [CrossRef]

91. Sayyah Gilani, M.; Iranmanesh, M.; Nikbin, D.; Zailani, S. EMR continuance usage intention of healthcare professionals. Inform. Health Soc. Care 2017, 42, 153-165. [CrossRef]

92. Kline, R.B. Principles and Practice of Structural Equation Modeling, 4th ed.; The Guilford Press: New York, NY, USA, 2016; ISBN 1462523358.

93. Zailani, S.; Iranmanesh, M.; Sean Hyun, S.; Ali, M.H. Applying the Theory of Consumption Values to Explain Drivers' Willingness to Pay for Biofuels. Sustainability 2019, 11, 668. [CrossRef]

94. Becker, J.-M.; Klein, K.; Wetzels, M. Hierarchical latent variable models in PLS-SEM: Guidelines for using reflective-formative type models. Long Range Plan. 2012, 45, 359-394. [CrossRef]

95. Hair, J.F.; Ringle, C.M.; Sarstedt, M. PLS-SEM: Indeed a silver bullet. J. Mark. Theory Pract. 2011, 19, 139-152. [CrossRef]

96. Foroughi, B.; Nikbin, D.; Hyun, S.S.; Iranmanesh, M. Impact of core product quality on sport fans' emotions and behavioral intentions. Int. J. Sports Mark. Spons. 2016, 17, 110-129. [CrossRef]

97. Iranmanesh, M.; Jayaraman, K.; Imrie, B.C.; Zailani, S. Promoting products through volume discount: Evidence from Malaysia. J. Promot. Manag. 2016, 22, 71-88. [CrossRef]

98. Zailani, S.; Jafarzadeh, S.; Iranmanesh, M.; Nikbin, D.; Selim, N.I.I. Halal logistics service quality: Conceptual model and empirical evidence. Br. Food J. 2018, 120, 2599-2614. [CrossRef] 
99. Chin, W.W. How to write up and report PLS analyses. In Handbook of Partial Least Squares: Concepts, Methods and Application; Vinzi, V.E., Chin, W.W., Eds.; Springer: Berlin/Heidelberg, Germany, 2010; pp. 655-690, ISBN 3540328254.

100. Latan, H.; Jabbour, C.J.C.; de Sousa Jabbour, A.B.L.; Wamba, S.F.; Shahbaz, M. Effects of environmental strategy, environmental uncertainty and top management's commitment on corporate environmental performance: The role of environmental management accounting. J. Clean. Prod. 2018, 180, 297-306. [CrossRef] article distributed under the terms and conditions of the Creative Commons Attribution (CC BY) license (http://creativecommons.org/licenses/by/4.0/). 